\title{
Layanan Bimbingan Dan Konseling Bagi Anak Berkebutuhan Khusus Melalui Pendekatan Islami Di Kelas Inklusi
}

\author{
Eka Sari Setianingsih \\ Universitas PGRI Semarang, Jawa Tengah, Indonesia \\ ekasari129@yahoo.com
}

\begin{abstract}
Abstrak
Penelitian dilakukan dengan tujuan menganalisis pelaksanaan pendidikan inklusi di SD Bina Harapan Semarang. Penelitian ini dilakukan dengan menggunakan metode kualitatif yang bersifat deskriptif analitis. Ketiadaan GPK serta kurikulum yang belum dimodifikasi menjadi permasalahan pelaksanaan pendidikan inklusi. Hasil penelitian menunjukkan pelaksanaan pendidikan inklusi belum sesuai dengan harapan. Hal ini disebabkan oleh belum adanya SK Penunjukkan Penyelenggaraa Pendidikan Inklusi di sekolah dan tidak menggunakan pendekatan islami sehingga pemenuhan berbagai komponen pendukung penyelenggaraan pendidikan inklusi belum bisa terpenuhi secara maksimal. Kesimpulannya adalah diperlukan adanya telaah dan tinjauan ulang tentang perizinan maupun pendekatan yang digunakan khususnya pendekatan islami untuk mendukung penyelenggaraan pendidikan inklusi seperti yang tertuang pada UUD 1945 pasal 31 Ayat 1.
\end{abstract}

Kata Kunci: bimbingan dan konseling, anak berkebutuhan khusus, pendekatan islami, pendidikan inklusi

\begin{abstract}
The research was done for the purpose analyze the implementation of the education inclusions in primary school bina hope semarang.The study is done by using the method qualitative is descriptive analytical. Surrounding the school lack of gpk as well as the curriculum that has not yet been modified has been a problem the implementation of the education of inclusion. The research results show the
\end{abstract}




\section{Layanan Bimbingan Dan Konseling ...}

implementation of the education of inclusion of its not based on hope.This is caused by the absence of sk the appointment of penyelenggaraa education inclusions in schools and not used the islamic approach So that the fulfillment of various the supporting component the implementation of education inclusion could not met in full. The conclusion is there needs to be review of and a review regarding licensing and approach that is used especially islamic approach to support the implementation of education inclusion As set out on of the indonesian constitution 1945 article 31 point 1.

Key words: guidance and counseling, children with special needs, islamic approach, education of inclusion

\section{A. Pendahuluan}

Perhatian besar pemerintah adalah pendidikan inklusi karena meningkatnya jumlah anak berkebutuhan khusus (ABK) di Indonesia. Pendidikan merupakan kebutuhan dasar setiap manusia untuk menjamin keberlangsungan hidupnya agar lebih bermartabat. Karena itu negara memiliki kewajiban untuk memberikan pelayanan pendidikan yang bermutu kepada setiap warganya tanpa terkecuali termasuk mereka yang memiliki perbedaan dalam kemampuan (difabel) seperti yang tertuang pada UUD 1945 pasal 31 (1). Namun sayangnya sistem pendidikan di Indonesia belum mengakomodasi keberagaman, sehingga menyebabkan munculnya segmentasi lembaga pendidikan yang berdasar pada perbedaan agama, etnis, dan bahkan perbedaan kemampuan baik fisik maupun mental yang dimiliki oleh siswa. Jelas segmentasi lembaga pendidikan ini telah menghambat para siswa untuk dapat belajar menghormati realitas keberagaman dalam masyarakat.

Undang-Undang Nomor 20 Tahun 2013 Tentang Sistem Pendidikan Nasional membuka jalan bagi anak-anak dengan kebutuhan khusus untuk dapat mengenyam pendidikan dengan layak. Pendidikan inklusi secara khusus diartikan sebagai sebuah upaya penyelenggaraan pendidikan yang diperuntukkan bagi anak berkebutuhan khusus dan anak normal untuk belajar. Dengan adanya pendidikan inklusi artinya sekolah tersebut harus mampu mengakomodasi setiap anak tanpa kecuali, baik secara fisik, intelektual, emosional, sosial, bahasa, budaya, etnis, minoritas dan 
berbagai hal lainnya. Tujuannya adalah tidak ada kesenjangan di antara anak berkebutuhan khusus dengan anak normal lainnya. Diharapkan pula anak dengan kebutuan khusus dapat memaksimalkan potensi yang ada dalam dirinya.

Lahirnya pendidikan inklusi sejalan dengan deklarasi PBB mengenai Hak Azasi Manusia (HAM), yaitu hak pendidikan dan partisipasi penuh bagi semua orang dalam pendidikan. Keberadaan pendidikan inklusi juga didukung oleh deklarasi yang disepakati oleh beberapa negara, termasuk Indonesia, antara lain adalah pernyataan Salamanca tahun 1994 mengenai hak setiap anak untuk mendapatkan pendidikan dan pengakuan terhadap perbedaan minat, kemampuan, dan kebutuhan dalam belajar.

Pendidikan inklusi di Indonesia dipayungi oleh UU No. 20 tahun 2003 tentang Sistem Pendidikan Nasional dan PP 19/2007 tentang Standar Nasional Pendidikan. Dalam undang-undang tentang sistem pendidikan nasional dijelaskan bahwa "setiap warga negara mempunyai hak yang sama untuk memperoleh pendidikan yang bermutu". Warga negara yang dimaksud adalah mereka yang memiliki bakat dan kecerdasan istimewa, mereka yang memiliki kelainan fisik, emosi, mental, intelektual dan sosial. Selanjutnya secara operasional di lapangan didukung oleh Permendiknas nomor 70 tahun 2009 tentang Pendidikan inklusi bagi peserta didik yang memiliki kelainan dan memiliki potensi kecerdasan dan/atau bakat istimewa.

Pemerintah melalui PP.No.19 tahun 2005 tentang Standar Nasional Pendidikan, pasal 41(1) telah mendorong terwujudnya sistem pendidikan inklusi dengan menyatakan bahwa setiap satuan pendidikan yang melaksanakan pendidikan inklusi harus memiliki tenaga kependidikan yang mempunyai kompetensi menyelenggarakan pembelajaran bagi peserta didik dengan kebutuhan khusus.

Seruan International Education For All (EFA) yang dikumandangkan UNESCO sebagai kesepakatan global hasil World Education Forum di Dakar, Senegal tahun 2000, penuntasan EFA diharapkan tercapai pada tahun 2015. Seruan ini senafas dengan semangat dan jiwa Pasal 31 UUD 1945 tentang hak setiap warga negara untuk memperoleh pendidikan dan Pasal 32 UU Sisdiknas 


\section{Layanan Bimbingan Dan Konseling ...}

Nomor 20 Tahun 2003 tentang Sistem Pendidikan Nasional yang mengatur mengenai Pendidikan Khusus dan Pendidikan Layanan Khusus.

Permendiknas Nomor 70 Tahun 2009 tentang pendidikan inklusi bagi peserta didik yang memiliki kelainan dan memiliki potensi kecerdasan dan/atau bakat istimewa menjadi aturan formal yang memayungi upaya pengembangan pendidikan inklusi di Indonesia. Peraturan menteri tersebut memuat dengan lengkap rambu-rambu mengenai pendidikan inklusi mulai dari perencanaan hingga pelaksanaan. Selain itu, Peraturan Menteri tersebut juga mewajibkan pemerintahan daerah kabupaten/kota untuk menunjuk minimal satu sekolah yang harus menyelenggarakan pendidikan inklusi.

Melalui pendidikan inklusi, anak berkelainan dididik bersama-sama anak lainnya (reguler) untuk mengoptimalkan potensi yang dimilikinya. Hal ini dilandasi oleh kenyataan bahwa di dalam masyarakat terdapat anak normal dan anak berkelainan yang tidak dapat dipisahkan sebagai suatu komunitas. Walaupun terkadang banyak pandangan-pandangan yang menganggap bahwa mereka dianggap sosok yang tidak berdaya, sehingga perlu dibantu dan dikasihani.

Pandangan di atas tidak sepenuhnya benar sangat merugikan anak-anak berkebutuhan khusus secara realistis, dengan melihat apa yang dapat dikerjakan oleh masing-masing anak. Setiap anak mempunyai kekurangan namun sekaligus mempunyai kelebihan. Oleh karena itu, dalam memandang anak berkebutuhan khusus (ABK), harus melihat dari segi kemampuan sekaligus ketidakmampuannya. Anak berkebutuhan khusus (ABK) hendaknya diberi perhatian lebih, baik dalam bentuk perhatian kasih sayang, pendidikan maupun dalam berinteraksi sosial.

Sebagai manusia, ABK memiliki hak untuk tumbuh kembang ditengah keluarga, masyarakat, dan bangsa. ABK memiliki hak untuk sekolah sama seperti saudara lainnya yang tidak memiliki kelainan atau normal. Tidak ada satu alasan bagi Sekolah Luar Biasa (SLB) dan Sekolah Dasar (SD) umum dimanapun adanya, melarang ABK untuk masuk ke sekolah tersebut. Bersama Guru Pembimbing Khusus yang telah memiliki pengetahuan dan keterampilan PLB, sekolah dapat 
merancang pelayanan PLB bagi anak tersebut yang sesuai dengan karakteristik dan kebutuhan anak.

Besar harapan bahwa pendidikan inklusi hendaknya lebih ditekankan pada pencapaian kualitas dan tidak berhenti pada penunjukkan semata terutama harapan bahwa peserta didik akan sehat secara fisik maupun rohani. Rumusan masalah dalam penelitian ini adalah bagaimanakah pelaksanaan pendidikan inklusi di SD Bina Harapan Semarang? Tujuan penelitian ini adalah untuk menganalisis pelaksanaan pendidikan inklusi SD Bina Harapan Semarang.

\section{B. Pembahasan}

Pendidikan inklusi merupakan perkembangan baru dari pendidikan terpadu. Pada sekolah inklusif setiap anak sesuai dengan kebutuhan khususnya, semua diusahakan dapat dilayani secara optimal dengan melakukan berbagai modifikasi dan atau penyesuaian, mulai dari kurikulum, sarana-prasarana, tenaga pendidik dan kependidikan, sistem pembelajaran sampai pada sistem penilaiannya.

Keuntungan dari pendidikan inklusi adalah bahwa anak berkebutuhan khusus maupun anak biasa dapat saling berinteraksi secara wajar sesuai dengan tuntutan kehidupan sehari-hari di masyarakat dan kebutuhan pendidikannya dapat terpenuhi sesuai dengan potensinya masing-masing. Pendidikan inklusi mensyaratkan pihak sekolah yang harus menyesuaikan dengan tuntutan kebutuhan individu peserta didik, bukan peserta didik yang menyesuaikan dengan sistem persekolahan. Pandangan mengenai pendidikan yang harus menyesuaikan dengan kondisi peserta didik ini sangat terkait dengan adanya perbedaan yang terdapat dalam diri peserta didik. Pandangan lama yang menyatakan bahwa peserta didiklah yang harus menyesuaikan dengan pendidikan dan proses pembelajaran di kelas lambat laun harus berubah. Istilah inklusi berimplikasi pada adanya kebutuhan yang harus dipenuhi bagi semua anak dalam sekolah. Hal ini menyebabkan adanya penyesuaian-penyesuaian yang harus dilakukan oleh guru dalam proses pembelajaran. 


\section{Layanan Bimbingan Dan Konseling ...}

Penyesuaian pendidikan (adaptive education) dilaksanakan dengan menyediakan pengalaman-pengalaman belajar guna membantu masing-masing peserta didik dalam meraih tujuan-tujuan pendidikan yang dikehendakinya. Penyesuaian pendidikan dapat berlangsung tatkala lingkungan pembelajaran sekolah dimodifikasi untuk merespon perbedaan-perbedaan peserta didik secara efektif dan mengembangkan kemampuan peserta didik agar dapat bertahan dalam lingkungan tersebut. Dengan melihat adanya penyesuaian terhadap kebutuhan peserta didik yang berbeda-beda, maka dalam setting pendidikan inklusi model pendidikan yang dilaksanakan memiliki model yang berbeda dengan model pendidikan yang lazim dilaksanakan di sekolah-sekolah reguler.

\section{Pengertian Pendidikan Inklusi}

Pendidikan inklusi dalam perkembangannya memiliki beberapa istilah yang berbeda, diantaranya: Special Education, Pendidikan Integratif, dan Pendidikan Bagi Anak Berkebutuhan Khusus. Loreman menyatakan bahwa ada banyak definisi pendidikan inklusi yang berkembang di masyarakat, dan memiliki interpretasi yang kadang-kadang salah atau misinterpretation, seperti kelas segregatif yang didalamnya berisi anak dengan tingkah laku bermasalah dikatakan telah melaksanakan pendidikan inklusi (Loreman, 2007 : 23).

Pendidikan inklusi seharusnya terdapat guru pembimbing khusus (GPK) yang diharapkan berkompetensi untuk mendampingi dan membimbing anak berkebutuhan khusus untuk dapat lebih baik. Pelaksanaan pendidikan inklusi tidak terlepas dari partisipasi keseluruhan tenaga pengajar yang ada di sekolah. Pendidikan inklusi bertujuan untuk memungkinkan siswa meraih potensi mereka (Marilyn Friend \& William D. Bursuck, 2015:5).

Hallahan et al. (2009:53) mengemukakan pengertian pendidikan inklusi sebagai pendidikan yang menempatkan semua peserta didik berkebutuhan khusus dalam sekolah reguler sepanjang hari. Dalam pendidikan seperti ini, guru memiliki tanggung jawab penuh terhadap peserta didik berkebutuhan khusus tersebut. Pengertian ini memberikan pemahaman bahwa pendidikan inklusi menyamakan anak berkebutuhan khusus dengan anak normal lainnya. 
Pendidikan inklusi juga bisa digunakan untuk mendeskripsikan penyatuan anak-anak berkelainan (penyandang hambatan/cacat) ke dalam program sekolah. Konsep inklusi memberikan pemahaman mengenai pentingnya penerimaan anakanak yang memiliki hambatan ke dalam kurikulum, lingkungan, dan interaksi sosial yang ada di sekolah (Smith 2006:45).

Menurut Hildegun Olsen (Tarmansyah, 2007: 82), pendidikan inklusi adalah sekolah harus mengakomodasi semua anak tanpa memandang kondisi fisik, intelektual, sosial emosional, linguistik atau kondisi lainnya. Pendidikan inklusi adalah sebuah pelayanan pendidikan bagi peserta didik yang mempunyai kebutuhan pendidikan khusus di sekolah regular (SD, SMP, SMU, dan SMK) yang tergolong luar biasa baik dalam arti kelainan, lamban belajar maupun berkesulitan belajar lainnya.

Menurut Staub dan Peck (Tarmansyah, 2007;83), pendidikan inklusi adalah penempatan anak berkelainan ringan, sedang dan berat secara penuh di kelas. Hal ini menunjukan kelas regular merupakan tempat belajar yang relevan bagi anak-anak berkelainan, apapun jenis kelainanya. Dari beberapa pendapat, maka dapat ditarik kesimpulan bahwa pendidikan inklusi adalah pelayanan pendidikan untuk peserta didik yang berkebutuhan khusus tanpa memandang kondisi fisik, intelektual, sosial emosional, linguistik atau kondisi lainnya untuk bersama-sama mendapatkan pelayanan pendidikan di sekolah regular (SD, SMP, SMU, maupun SMK).

Berdasarkan pengertian-pengertian di atas dapat ditarik kesimpulan bahwa pendidikan inklusi adalah pelayanan pendidikan untuk peserta didik yang berkebutuhan khusus tanpa memandang kondisi fisik, intelektual, sosial emosional, linguistik atau kondisi lainnya untuk bersama-sama mendapatkan pelayanan pendidikan di sekolah regular (SD, SMP, SMU, maupun SMK). Seperti yang telah disampaikan bahwa pendidikan inklusi memberikan kesempatan kepada semua peserta didik yang memiliki kelainan dan memiliki potensi kecerdasan dan/atau bakat istimewa untuk mengikuti pendidikan atau pembelajaran dalam lingkungan pendidikan secara bersama-sama dengan peserta didik pada umumnya.

Pendidikan inklusi pada dasarnya memiliki dua model. Pertama yaitu model inklusi penuh (full inclusion), berarti 


\section{Layanan Bimbingan Dan Konseling ...}

penghapusan pendidikan khusus. Model ini menyertakan peserta didik berkebutuhan khusus untuk menerima pembelajaran individual dalam kelas reguler. Kedua yaitu model inklusif parsial (partial inclusion). Model parsial ini mengikutsertakan peserta didik berkebutuhan khusus dalam sebagian pembelajaran yang berlangsung di kelas reguler dan sebagian lagi dalam kelas-kelas pull out dengan bantuan guru pendamping khusus.

Model lain misalnya dikemukakan oleh Brent Hardin dan Marie Hardin. Brent dan Maria mengemukakan model pendidikan inklusi yang mereka sebut inklusif terbalik (reverse inclusive). Dalam model ini, peserta didik normal dimasukkan ke dalam kelas yang berisi peserta didik berkebutuhan khusus. Model ini berkebalikan dengan model yang pada umumnya memasukkan peserta didik berkebutuhan khusus ke dalam kelas yang berisi peserta didik normal. Model inklusi terbalik agaknya menjadi model yang kurang lazim dilaksanakan. Model ini mengandaikan peserta didik berkebutuhan khusus sebagai peserta didik dengan jumlah yang lebih banyak dari peserta didik normal. Dengan pengandaian demikian seolah sekolah untuk anak berkebutuhan khusus secara kuantitas lebih banyak dari sekolah untuk peserta didik normal, atau bisa juga tidak. Model pendidikan inklusif seperti apapun tampaknya tidak menjadi persoalan berarti sepanjang mengacu kepada konsep dasar pendidikan inklusi

Model pendidikan inklusi yang diselenggarakan pemerintah Indonesia yaitu model pendidikan inklusi moderat. Pendidikan inklusi moderat yang dimaksud yaitu pendidikan inklusi yang memadukan antara terpadu dan inklusi penuh. Model moderat ini dikenal dengan model mainstreaming. Model pendidikan mainstreaming merupakan model yang memadukan antara pendidikan untuk anak berkebutuhan khusus (Sekolah Luar Biasa) dengan pendidikan reguler. Peserta didik berkebutuhan khusus digabungkan ke dalam kelas reguler hanya untuk beberapa waktu saja. Salah satu usaha awal dalam menawarkan suatu model mainstreaming menurut Berry, menekankan tiga unsur yang harus mempunyai ciri-ciri itu: suatu rangkaian jenis-jenis layanan pendidikan bagi siswa-siswa yang memiliki hambatan, pengurangan jumlah anak-anak yang "ditarik keluar" dari kelas-kelas reguler, dan 
penambahan ketetapan-ketetapan bagi layanan pendidikan di dalam kelas-kelas reguler ketimbang di luar kelas-kelas tersebut.

SD Bina Harapan Semarang merupakan salah satu SD di Semarang Kota yang menyelenggarakan pendidikan inklusi meskipun belum mempunyai SK Penunjukan Penyelenggaraan Pendidikan Inklusi Tingkat SD, secara formal perizinan SD Bina Harapan adalah Sekolah Inklusi namun pada kenyataannya yang kami temukan di lapangan adalah bahwa SD Bina Harapan didominasi oleh siswa ABK sedangkan kurikulum yang digunakan adalah kurikulum reguler. Berdasarkan pernyataan Kepala Sekolah di atas tampak bahwa Kepala SD Bina Harapan Semarang sudah memahami bahwa bahwa konsep pendidikan inklusi memiliki lebih banyak kesamaan dengan konsep yang melandasi 'Pendidikan untuk Semua', dan 'Peningkatan mutu sekolah'.

Selanjutnya disampaikan pula, bahwa pendidikan inklusi merupakan pergeseran dari kecemasan tentang suatu kelompok tertentu menjadi upaya yang difokuskan untuk mengatasi hambatan untuk belajar dan berprestasi. Pendidikan inklusi adalah sistem layanan pendidikan yang mensyaratkan anak berkebutuhan khusus belajar di sekolah-sekolah terdekat di kelas biasa bersama-sama teman seusianya. Namun kenyataannya setiap tahun siswa yang mendaftar pada SD Bina Harapan Semarang justru selalu anak-anak berkebutuhan khusus, sehingga yang diterima hanyalah siswa ABK yang ketunaannya masih ringan dengan harapan guru-guru regular mampu menangani.

Data dilapangan menunjukkan bahwa di SD Bina Harapan mayoritas justru anak berkebutuhan khusus (ABK) maka hal ini tentu saja tidak sesuai dengan konsep pendidikan inklusi yang telah diuraikan pada bab sebelumnya, bahwa Sekolah penyelenggara pendidikan inklusi adalah sekolah yang menampung semua murid di sekolah yang sama. Sekolah ini menyediakan program pendidikan yang layak dan menantang, tetapi disesuaikan dengan kemampuan dan kebutuhan setiap murid maupun bantuan dan dukungan yang dapat diberikan oleh para guru agar murid-murid berhasil secara optimal.

Pendidikan inklusi adalah pendidikan yang menyertakan semua anak secara bersama-sama dalam suatu iklim dan proses 


\section{Layanan Bimbingan Dan Konseling ...}

pembelajaran dengan layanan pendidikan yang layak dan sesuai dengan kebutuhan individu siswa tanpa membeda-bedakan anak yang berasal dari latar suku, kondisi sosial, kemampuan ekonomi, politik, keluarga, bahasa, geografis (keterpencilan) tempat tinggal, jenis kelamin, agama, dan perbedaan kondisi fisik atau mental. Sedangkan di SD Bina Harapan Semarang tidak demikian keadaannya.

\section{Tujuan Pendidikan Inklusi}

Tujuan pendidikan inklusi menurut Raschake dan Bronson ( dalam Lay Kekeh Marthan, 2007:189-190), terbagi menjadi 3 yakni bagi anak berkebutuhan khusus, bagi pihak sekolah, bagi guru, dan bagi masyarakat, lebih jelasnya adalah sebagai berikut: a) Bagi anak berkebutuhan khusus; 1) Anak akan merasa menjadi bagian dari masyarakat pada umumnya, 2) Anak akan memperoleh bermacammacam sumber untuk belajar dan bertumbuh., 3) Meningkatkan harga diri anak, 4) Anak memperoleh kesempatan untuk belajar dan menjalin persahabatan bersama teman yang sebaya, 5) Memberikan kesempatan yang seluas-luasnya kepada semua anak (termasuk anak berkebutuhan khusus) mendapatkan pendidikan yang layak sesuai dengan kebutuhannya. b) Bagi pihak sekolah; 1) Memperoleh pengalaman untuk mengelola berbagai perbedaan dalam satu kelas, 2) Mengembangkan apresiasi bahwa setiap orang memiliki keunikan dan kemampuan yang berbeda satu dengan lainnya, 3) Meningkatkan kepekaan terhadap keterbatasan orang lain dan rasa empati pada keterbatasan anak, 4) Meningkatkan kemampuan untuk menolong dan mengajar semua anak dalam kelas. c) Bagi guru; 1) Membantu guru untuk menghargai perbedaan pada setiap anak dan mengakui bahwa anak berkebutuhan khusus juga memiliki kemampuan, 2) Menciptakan kepedulian bagi setiap guru terhadap pentingnya pendidikan bagi anak berkebutuhan khusus, 3) Guru akan merasa tertantang untuk menciptakan metode-metode baru dalam pembelajaran dan mengembangkan kerjasama dalam memecahkan masalah, 4) Meredam kejenuhan guru dalam mengajar. d) Bagi masyarakat; 1) Meningkatkan kesetaraan sosial dan kedamaian dalam masyarakat, 2) Mengajarkan kerjasama dalam masyarakat dan mengajarkan setiap anggota masyarakat tentang proses demokrasi, 
3) Membangun rasa saling mendukung dan saling membutuhkan antar anggota masyarakat.

Layanan pendidikan inklusi bagi siswa ABK di SD Bina Harapan Semarang belum bisa maksimal, sebab mekanisme manajemen yang digunakan masih menggunaan mekanisme manajemen sekolah regular sedangkan mayoritas siswa di SD Bina Harapan Semarang adalah siswa ABK. Padahal dalam penyelenggaraan pendidikan inklusi harus menggunakan manajemen pendidikan inklusi baik dari segi kesiswaan, kurikulum, tenaga kependidikan, sarana dan prasarana, keuangan/ dana, lingkungan (hubungan sekolah dan masyarakat) serta layanan khusus.

Dalam hal penerimaan siswa baru, Kepala sekolah SD Bina Harapan Semarang akan menentukan apakah siswa yang bersangkutan diterima atau tidak berdasarkan tingkat kebutuhan khusus yang dimiliki oleh siswa dalam kategori ringan dan sedang, karena pada kenyataannya yang mendaftar tiap tahun adalah kategori anak berkebutuhan khusus bukan siswa reguler. Apabila termasuk dalam kategori ringan sampai sedang maka akan diterima, tetapi apabila dalam kategori berat akan disarankan sekolah di SLB.

Dikarenakan SD Bina Harapan Semarang bukan sekolah inklusi berdasarkan SK Penunjukkan Penyelenggaraan Pendidikan Inklusi maka penerimaan siswa $\mathrm{ABK}$ dilakukan berdasarkan kebutuhan di masyarakat. Apabila merujuk pada Permendiknas No. 1 Tahun 2008 tentang Standar Proses Pendidikan untuk Tunanetra, Tunarungu, Tunagrahita, Tunadaksa dan Tunalaras, bahwa penerimaan siswa berkebutuhan khusus pada setiap satuan pendidikan yang menyelenggarakan pendidikan inklusi perlu mempertimbangkan sumber daya yang dimiliki sekolah, satuan pendidikan tersebut harus mengalokasikan kursi siswa (quota) paling sedikit satu (1) siswa yang memiliki kelainan dalam satu rombongan belajar yang akan diterima dan paling banyak disesuaikan dengan kekuatan dan daya dukung sekolah.

Program bimbingan dan penyuluhan diadakan berdasarkan kebutuhan siswa. Yakni SD Bina Harapan Semarang telah bekerjasama dengan UNIKA untuk untuk mengadakan tes psikologi dan USM pada setiap semester akan diadakan pembekalan bagi guru 


\section{Layanan Bimbingan Dan Konseling ...}

SD Bina Harapan terkait dengan kebutuhan dalam melayani siswa ABK di Sekolah.

Di SD Bina Harapan Semarang, kurikulum yang dimiliki masih menggunakan kurikulum reguler, sehingga kebutuhan dan penanganan siswa ABK belum bisa terakomodir dengan baik padahal semua siswa termasuk siswa ABK.

Manajemen tenaga kependidikan antara lain adalah 1) inventarisasi pegawai, 2) pengusulan formasi pegawai, 3) pengusulan pengangkatan, 4) mengatur usaha kesejahteraan, 5) mengatur pembagian tugas. Tenaga kependidikan bertugas menyelenggarakan kegiatan mengajar, melatih, meneliti, mengembangkan, mengelola dan/atau meberikan pelayanan teknis dalam bidang pendidikan. Tenaga kependidikan di sekolah inklusi sebagian besar sama dengan sekolah regular meliputi guru, laboran, dan teknis sumber belajar.

Lebih khusus, tenaga kependidikan yang dimiliki sekolah inklusi adalah guru kelas, guru mata pelajaran dan guru pendamping khusus (GPK). Di SD Bina Harapan Semarang semua hal tersebut belum dilakukan karena keterbatasan banyak hal. Manajemen tenaga pendidikan dilakukan sesuai dengan standar reguler. Serta keterbetasan guru regular pada pemahaman siswa ABK hanya diperoleh berdasarkan keseharian dalam menangani siswa ABK (Otodidak).

Untuk menambah wawasan guru-guru regular maka sekolah sesekali secara rutin sesuai alokasi anggaran yang dimiliki akan mengirim 2 guru tiap 3 bulan sekali untuk mengukuti pelatihanpelatihan dan pendampingan ABK pada pendidikan inklusi.

Serta pihak sekolah telah bekerjasama dengan fakultas psikologi USM dan UNIKA, dalam 6 bulan sekali dari pihak kampus akan mengadakan pelatihan dan pendampingan bagi guru-guru dan karyawan atau staf TU yang ada di SD Bina Harapan Semarang. Sehingga jika sewaktu proses pembelajaran dikelas guru membutuhkan bantuan pendamping maka staf TU akan membantu mendampingi beberapa siswa di kelas.

Sarana dan prasarana di SD Bina Harapan Semarang belum memenuhi standar sarpras yang sebagaimana tercantum dalam Permendiknas, hal ini desebabkan karena tidak adanya alokasi dana 
untuk penyediaan sarpras bagi siswa ABK. Serta peralatan sarpras ABk yang tergolong mahal menyulitkan sekolah untuk memenuhinya. Beberapa kali SD Bina Harapan Semarang mendapatkan BOP dan beasiswa pendidikan inklusi, dan dari pembayaran SPP dialokasikan untuk pemenuhan sarpras.

Kepala SD Bina Harapan Semarang selalu berupaya untuk melibatkan masyarakat termasuk orangtua wali siswa yang tergabung dalam Komite Sekolah, termasuk untuk menangani siswa ABK. Tetapi meskipun demikian karena keterbatasan pengetahuan masyarakat tentang penyelenggaraan pendidikan inklusi di sekolah, banyak diantara anggota komite yang ikut serta mempercayakan saja semua keputusan pada pihak sekolah.

\section{Anak Berkebutuhan Khusus (ABK)}

Anak Berkebutuhan Khusus (ABK) adalah sebagai pengganti istilah lama anak cacat atau penyandang cacat. Sebenarnya istilah Anak Bekebutuhan Khusus adalah untuk menunjuk mereka yang memiliki kelainan fisik, emosional, mental, intelektual, dan/atau sosial. Pemerintah memahami pada kondisi yang memiliki kekurangan dan kelebihan kemampuan khususnya dalam bidang pendidikan. Itulah Anak Berkebutuhan Khusus.

Hak anak adalah bagian dari hak asasi manusia yang wajib dijamin, dilindungi, dan dipenuhi oleh orang tua, keluarga, masyarakat, pemerintah, dan negara. Hak anak yang wajib dipenuhi diantaranya adalah hak untuk memperoleh pendidikan dan pengajaran. Anak berkebutuhan khusus usia dini juga berhak mendapatkan layanan pendidikan.

Anak berkebutuhan khusus harus mendapatkan perlakuan yang sama dalam memperoleh pendidikan yang layak dan bermutu. Agar anak berkebutuhan khusus mendapat pengajaran yang benar maka perlu diiperhatikan jenis-jenis berkebutuhan khusus (ABK).

Tunanetra, anak yang mengalami gangguan daya penglihatannya, berupa kebutaan menyeluruh atau sebagian, dan walaupun telah diberi pertolongan dengan alat-alat bantu khusus masih tetap memerlukan pelayanan pendidikan khusus. Tunarungu, anak yang kehilangan seluruh atau sebagian daya pendengarannya sehingga tidak atau kurang mampu berkomunikasi secara verbal dan walaupun telah diberikan pertolongan dengan alat bantu dengar 


\section{Layanan Bimbingan Dan Konseling ...}

masih tetap memerlukan pelayanan pendidikan khusus. Tunalaras, anak yang mengalami kesulitan dalam penyesuaian diri dan bertingkah laku tidak sesuai dengan norma-norma yang berlaku dalam lingkungan kelompok usia maupun masyarakat pada umumnya, sehingga merugikan dirinya maupun orang lain. Tunadaksa, anak yang mengalami kelainan atau cacat yang menetap pada alat gerak (tulang, sendi, otot) sedemikian rupa sehingga memerlukan pelayanan pendidikan khusus. Tunagrahita, anak yang secara nyata mengalami hambatan dan keterbelakangan perkembangan mental jauh di bawah rata-rata (IQ dibawah 70) sehingga mengalami kesulitan dalam tugas-tugas akademik, komunikasi maupun sosial, dan karenanya memerlukan layanan pendidikan khusus. Hambatan ini terjadi sebelum umur 18 tahun.

Cerebral palsy, gangguan /hambatan karena kerusakan otak (brain injury) sehingga mempengaruhi pengendalian fungsi motorik. Gifted, anak yang memiliki potensi kecerdasan (intelegensi), kreativitas, dan tanggung jawab terhadap tugas (task commitment) di atas anak-anak seusianya (anak normal). Autistis atau autisme, gangguan perkembangan anak yang disebabkan oleh adanya gangguan pada sistem syaraf pusat yang mengakibatkan gangguan dalam interaksi sosial, komunikasi dan perilaku.

Asperger Disorder atau AD, gangguan pada anak Asperger lebih ringan dibandingkan anak autisme dan sering disebut dengan istilah High-fuctioning autism. Rett's Disorde, jenis gangguan perkembangan yang masuk kategori ASD. Aspek perkembangan pada anak Rett's Disorder mengalami kemuduran sejak menginjak usia 18 bulan yang ditandai hilangnya kemampuan bahasa bicara secara tiba-tiba. Koordinasi motorinya semakin memburuk dan dibarengi dengan kemunduran dalam kemampuan sosialnya. Rett's Disorder hampir keseluruhan penderitanya adalah perempuan.

Attention deficit disorder with hyperactive atau ADHD, bisa juga disebut anak hiperaktif, oleh karena mereka selalu bergerak dari satu tempat ketempat yang lain. Tidak dapat duduk diam di satu tempat selama \pm 5-10 menit untuk melakukan suatu kegiatan yang diberikan kepadanya. Rentang konsentrasinya sangat pendek, mudah bingung dan pikirannya selalu kacau, sering mengabaikan perintah atau arahan, sering tidak berhasil dalam menyelesaikan tugas-tugas 
di sekolah. Sering mengalami kesulitan mengeja atau menirukan ejaan huruf.

Lamban belajar atau slow learner, anak yang memiliki potensi intelektual sedikit di bawah normal tetapi belum termasuk tunagrahita. Dalam beberapa hal mengalami hambatan atau keterlambatan berpikir, merespons rangsangan dan adaptasi sosial, tetapi masih jauh lebih baik dibanding dengan yang tunagrahita.

Anak yang mengalami kesulitan belajar spesifik, anak yang secara nyata mengalami kesulitan dalam tugas-tugas akademik khusus (terutama dalam hal kemampuan membaca, menulis dan berhitung atau matematika). dari jenis-jenis anak berkebutuhan khusus tersebut kita dapat mengetahui kendala dan kekurangan mereka. Sebagai orang awam pun kita dapat memahami dan mengerti apa yang menjadi kendala dari mereka.

Jika dikaji bentuk perhatian pemerintah, pemerintah peduli dengan anak berkebutuhan khusus ini dengan bukti di tiap daerah mulai didirikan Sekolah Luar Biasa (SLB). Tak tanggung-tanggung, universitas-universitas memiliki jurusan untuk menjadi guru SLB. Inilah bukti pemerintah telah peduli kepada semua masyarakat, terkhusus anak-anak, karena anak-anak merupakan harapan bangsa.

Namun, upaya pemerintah tidak akan berhasil jika para orangtua tidak memanfaatkan fasilitas yang telah diberikan pemerintah. Adalah hak dan kewajiban setiap warga negara menempuh pendidikan, tidak terkecuali bagi mereka anak-anak berkebutuhan khusus. Jika anak-anak berkebutuhan khusus sudah di didik dari tingkat sekolah sejajar dengan teman mereka lainnya, maka mereka akan mengerti dan memahami pembelajaran seperti yang lainnya, walaupun tentu dengan kadar yang berbeda. Hendaknya para orangtua mulai memperhatikan betapa pentingnya pendidikan bagi anak-anak baik yang normal maupun anak dengan kebutuhan khusus.

Konsep anak berkebutuhan khusus dapat dikategorikan menjadi dua kelompok besar yaitu anak berkebutuhan khusus yang bersifat sementra (temporer) dan anak berkebutuhan khusus yang besifat menetap (permanent). 


\section{Layanan Bimbingan Dan Konseling ...}

\section{a. Anak Berkebutuhan Khusus Bersifat Sementra (Temporer)}

Anak berkebutuhan khusus yang bersifat sementara (temporer) adalah anak yang mengalami hambatan belajar dan hambatan perkembangan disebabkan oleh faktor-faktor eksternal. Misalnya anak yang yang mengalami gangguan emosi karena trauma akibat diperekosa sehingga anak ini tidak dapat belajar. Pengalaman traumatis seperti itu bersifat sementra tetapi apabila anak ini tidak memperoleh intervensi yang tepat boleh jadi akan menjadi permanent.

\section{b. Anak Berkebutuhan Khusus yang Bersifat Menetap (Permanen)}

Anak berkebutuhan khusus yang bersifat permanen adalah anak-anak yang mengalami hambatan belajar dan hambatan perkembangan yang bersifat internal dan akibat langsung dari kondisi kecacatan, yaitu seperti anak yang kehilangan fungsi penglihatan, pendengaran, gannguan perkembangan kecerdasan dan kognisi, gannguan gerak (motorik), gannguan iteraksi-komunikasi, gannguan emosi, social dan tingkah laku. Dengan kata lain anak berkebutuhan khusus yang bersifat permanent sama artinya dengan anak penyandang kecacatan.

Heward (2003) mendefinisikan ABK sebagai anak dengan karakteristik khusus yang berbeda dengan anak pada umumnya tanpa selalu menunjukkan pada ketidak mampuan mental, emosi , atau fisik. Suran dan Rizzo (dalam Semiawan dan Mangunson,2010) ABK adalah anak yang secara signifikan berbeda dalam beberapa dimensi yang penting dari fungsi kemanusiaannya. Mereka yang secara fisik, psikologis, kognitif, atau sosial terlambat dalam mencapai tujuan-tujuan atau kebutuhan dan potensinya secara maksimal, meliputi mereka yang tuli, buta, gangguan bicara, cacat tubuh, retardasi mental, gangguan emosional, juga anak-anak berbakat dengan inteligensi tinggi termasuk kedalam kategori anak berkebutuhan khusus karena memerlukan penanganan dari tenaga profesional terlatih.

Berdasarkan beberapa definisi yang telah diberikan oleh para tokoh di atas, dapat disimpulkan bahwa ABK adalah individu yang memiliki karakteristik fisik, intelektual, maupun emosional, di atas atau di bawah rata-rata inividu pada umumnya. 
Istilah anak berkebutuhan khusus merupakan istilah terbaru yang digunakan dan merupakan terjemahan dari children with special need yang telah digunakan secara luas di dunia internasional. Ada beberapa istilah lain yang digunakan untuk menyebut anak berkebutuhan khusus. antara lain anak cacat, anak tuna, anak berkelainan, anak menyimpang, dan anak luar biasa. Selain itu, WHO juga merumuskan beberapa istilah yang digunakan untuk menyebut anak berkebutuhan khusus, yaitu: a) Impairement: merupakan suatu keadaan atau kondisi dimana individu mengalami kehilangan atau abnormalitas psikologi, fisiologi atau fungsi struktur anatomi secara umum pada tingkat organ tubuh. Contoh seorang yang mengalami amputasi satu kaki, maka ia mengalami kecacatan kaki, b) Disability: merupakan suatu keadaan dimana individu menjadi "kurang mampu" melakukan kegiatan sehari-hari karena adanya keadaan impairement, seperti kecacatan pada organ tubuh. Contoh, pada orang yang cacat kaki, dia akan merasakan berkurangnya fungsi kaki untuk mobilitas, c) Handicaped: suatu keadaan dimana individu mengalami ketidak mampuan dalam bersosialisasi dan berinteraksi dengan lingkungan. Hal ini dimungkinkan karena adanya kelainan dan berkurangnya fungsi organ individu. Contoh orang yang mengalami amputasi kaki, dia akan mengalami masalah mobilitas sehingga dia memerlukan kursi roda (Purwanti,2012).

Manajemen layanan khusus di SD Bina Harapan Semarang dilakukan dalam hal-hal khusus. Contohnya: untuk membantu siswa ABK dalam kebutuhan khusus maka akan diberikan layanan dan treatment khusus pada siswa yang bersangkutan oleh psikolog yang hadir ke sekolah dalam seminggu sekali, terjadwal siapa saja siswa yang akan mendapatkan pelayanan dan treatment khusus pada minggu itu maka psikolog yang ada akan memberikan layanan tersebut sesuai ketunaan siswa.

Layanan khusus pada penyelenggaraan pendidikan inklusi dilakukan berdasarkan kebutuhan siswa ABK. Sehingga pelaksanaan di setiap sekolah inklusi akan berbeda-beda sesuai kebutuhan akan ketunaannya.

\section{Pendekatan Islami di Kelas Inklusi}

Bimbingan islami adalah proses pemberian bantuan terhadap individu agar mampu hidup selaras dengan ketentuan dan petunjuk 


\section{Layanan Bimbingan Dan Konseling ...}

Allah,sehinngga dapat mencapai kebahagiaan hidup didunia dan akhirat. Dengan demikian bimbingan islam merupakan proses bimbingan sebagaimana kegiatan bimbingan lainnya, tetapi dalam seluruh seginya berlandaskan Al-quran dan sunnah rasul.

Bimbingan islam merupakan proses bimbingan bantuan,artinya bimbingan tidak menentukan atau mengharuskan, melainkan sekedar membantu individu.Individu dibantu, dibimbing, agar mampu hidup selaras dengan ketentuan dan petunjuk Allah.

Landasan (fondasi atau dasar pijak) utama bimbingan dan konseling islami adalah al-quran dan sunnah rasul, sebab keduanya merupakan sumber dari segala sumber pedoman kehidupan umat Islam,seperti disebutkan Nabi Muhammad saw sebagai berikut yang artinya: "Aku tinggalkan sesuatu bagi kalian semua yang jika kalian selalu berpegang teguh kepadanya niscaya selamanya-selamanya tidak akan pernah salah langkah tidak akan pernah salang langkah tersesat jalan, sesuatu itu yakni kitabullah dan sunah Rasulnya."

Sejalan dengan bimbingan dan konseling konvensional, bimbingan dan konseling Islami mengandaikan adanya hubungan personal antar manusia, satu pihak yang ingin memecahkan masalah, dan pihak lain yang membantu menyelesaikan masalah tersebut. Dalam hal ini, MD. Dahlan mengungkapkan bahwa bimbingan dan konseling Islami adalah "bimbingan kehidupan yang pada intinya tertuju pada realisasi doa rabanna atina fi ad-dunya hasanah wa fil akhirati hasanah wa qina adzaba an-nar. Berisikan rintisan jalan ke arah penyadaran kepribadian manusia sebagai makhluk Allah dan dapat menumbuhkan rasa tentram dalam hidup karena selalu merasa dekat dengan Allah dan ada dalam lindungan-Nya."

Secara garis besar atau secara umum, tujuan bimbingan dan konseling Islami itu dapat dirumuskan sebagai "membantu individu mewujudkan dirinya sebagai manusia seutuhnya agar mencapai kebahagiaan hidup di dunia dan di akhirat"

Salah satu tujuan dari bimbingan dan konseling Islam adalah mengarahkan kepada individu untuk mempunyai mental atau jiwa yang sehat. Untuk mencapai tujuan bimbingan dan konseling Islam, maka dibutuhkan sebuah langkah operasional untuk mengarahkan individu untuk mempunyai mental atau jiwa yang sehat. 
Salah satu tokoh dalam Islam yang membahas tentang problematika jiwa adalah Al-Ghazali. Ia secara terperinci telah menjelaskan tentang jiwa dan bagaimana mengobati problematika yang berkaitan dengan jiwa. Kedua masalah tersebut dibahas dalam bab keajaiban hati dan riyâdhah al-nafs. Di dalam kajian tersebut AlGhazali tidak hanya menjelaskan tentang perilaku manusia, tetapi juga memberikan terapi penanggulangan permasalahanpermasalahan yang berkaitan dengan perilaku manusia.

Hakekat bimbingan dan konseling Islami adalah upaya membantu individu belajar mengembangkanfitrah dan atau kembalikepada fitrah, dengan cara memberdayakan (empowering) iman, akal, dan kemauan yang dikaruniakan Aloh SWT. Kepadanya untuk mempelajari tuntunan Allah dan rasul-Nya, agar fithrah yang ada pada individu itu berkembang dengan benar dan kokoh sesuai tuntunan Allah SWT.

Dari rumusan di atas nampak, bahwa konseling Islami adalah aktifitas yang bersifat "membantu", dikatakan membantu karena pada hakekatnya individu sendirilah yang perlu hidup sesuai tuntunan Allah (jalan yang lurus) agar mereka selamat. Karena posisi konselor bersifat membantu, maka konsekuensinya individu sendiri yang harus aktif belajar memahami dan sekaligus melaksanakan tuntunan Islam (Al-Quran dan sunnah rasul-Nya). Pada akhirnya diharapkan agar individu selamat dan memperoleh kebahagiaan yang sejati di dunia dan akhirat, bukan sebaliknya kesengsaraan dan kemelaratan di dunia dan akhirat.

Pihak yang membantu adalah konselor, yaitu seorang mu'min yang memiliki pemahaman yang mendalam tentang tuntunan Allah dan mentaatinya. Bantuan itu terutama berbentuk pemberian dorongan dan pendampingan dalam memahami dan mengamalkan syari'at Islam. Dengan memahami dan mengamalkan syari'at Islam itu diharapkan segala potensi yang dikaruniakan Allah kepada individu bisa berkembang optimal. Akhirnya diharapkan agar individu menjadi hamba Allah yang muttaqin mukhlasin, mukhsinin, dan mutawakkilin; yang terjauh dari godaan syetan, terjauh dari tindakan ma'siat, dan ikhlas melaksanakan ibadah kepada Allah.

Individu yang dibantu adalah manusia-bukan binatang yang setelah meninggal sudah tidak ada tanggung jawab lagi, individu 


\section{Layanan Bimbingan Dan Konseling ...}

dipandang sebagai "hamba Allah" yang harus selalu tunduk dan patuh kepada-Nya. Manusia diciptakan bukan hanya untuk bersenang-senang, tetapi di sana ada perintah yang harus dilakukan dan larangan yang harus dijauhi, da nada peraturan yang harus ditaati. Oleh sebab itu dalam kegiatan bimbingan, individu perlu dikenalkan siapa sebenarnya dia, dan aturan yang harus dipatuhi dan larangan yang harus dijauhi, seta tanggung jawab dari apa yang mereka kerjakan selama hidup di dunia. Dalam belajar memahami diri dan memahami aturan Allah yang harus dipatuhi tidak jarang mereka mengalami kegagalan, oleh sebab itu mereka membutuhkan banuan khusus yang disebut "konseling islami" atau bisa disebut juga dengan pendekatan islami.

Pendekatan islami di kelas inklusi atau layanan bimbingan islami adalah salah satu kegiatan layanan bimbingan untuk siswa agar dapat menemukan dan mengembangkan pribadi yang beriman dan bertaqwa kepada Tuhan YME, mantap dan mandiri serta sehat jasmani dan rohani mandiri serta mampu mengoptimalkan potensi yang dimiliki sesuai dengan ajaran agama Islam.

Bagi anak berkebutuhan khusus, layanan bimbingan pribadi Islami dilaksanakan diantaranya adalah agar semua siswa mampun mengamalkan nilai-nilai keimanan dan ketaqwaan kepada Allah, memahami perasaan diri dan mampu mengekspresikannya secara wajar, mengembangkan potensi diri melalui berbagai aktivitas yang positif, menghayati nilai-nilai agama sebagai pedoman dalam berperilaku.

Pendekatan islami dapat di impelemtasikan dalam kegiatan sehari-hari bagi siswa berkebutuhan khusus, diantaranya pendampingan saat siswa berdo'a sebelum dan sesudah pembelajaran, pembimbingan untuk senantiasa mengucapakan kalimat-kalimat toyibah selama mengikuti kegiatan pembelajaran seperti mengucap bismillah ketika akan melakukan sesuatu membaca alhamdulillah ketika selesai melakukan sesuatu, bimbingan tata cara ibadah harian, dan lain-lain.

Layanan bimbingan dengan pendekatan Islami yang dilaksanakan di sekolah inklusi tentu tidak dapat berjalan dengan mulus tanpa adanya hambatan, ada banyak hal yang menjadi persoalan dalam pelaksanaan layanan bimbingan dengan 
pendekatan islami yang dilaksanakan. Hal itu disebabkan oleh kompleksnya permasalahan yang ada di kelas inklusi. Kelas dimana siswa dengan bermacam-macam kemampuan dan keunikan kebutuhan yang dimiliki. Selain itu, banyak permasalahan yang dihadapi dalam melaksanakan layanan bimbingan pribadi Islami adalah karena siswa ABK cenderung memiliki emosi yang labil, memiliki kebiasaan-kebiasaan buruk, dan kekurangmampuan dalam berkomunikasi sehingga dalam pelaksanaan bimbingan dengan pendekatan Islami yang dilaksanakan cenderung tidak dapat berjalan dengan baik dan sebagaimana harapan.

Umumnya sekolah inklusi adalah sekolah yang menggabungkan siswa reguler (normal) dengan siswa berketunaan (ABK) namun di SD Bina Harapan semua siswa adalah siswa berkategori ABK. Tidak ada siswa reguler. Kepala sekolah SD Bina Harapan Semarang yang menentukan apakah siswa yang bersangkutan diterima atau tidak berdasarkan tingkat kebutuhan khusus yang dimiliki oleh siswa dalam kategori ringan dan sedang, karena pada kenyataannya yang mendaftar tiap tahun adalah kategori anak berkebutuhan khusus bukan siswa reguler. Apabila termasuk dalam kategori ringan sampai sedang maka akan diterima, tetapi apabila dalam kategori berat akan disarankan sekolah di SLB.

Sedangkan guru-guru yang ada adalah guru regular yang minim pengetahuan tentang $\mathrm{ABK}$, adapun pengetahuan dan pelayanan guru yang diberikan kepada siswa ABK di SD Bina Harapan Semarang bersifat otodidak karena penanganan keseharian/kebiasaan menangani siswa ABK sehari-hari saja. Lebih khusus, tenaga kependidikan yang dimiliki sekolah inklusi adalah guru kelas, guru mata pelajaran. Sehingga penggunaan pendekatan islami di kelas inklusi pada SD Bina Harapan Semarang tidak diterapkan.

\section{Simpulan}

Implementasi pendidikan inklusi dan pendekatan islami bagi Anak Berkebutuhan Khusus (ABK) di SD Bina Harapan Semarang belum dikatakan maksimal dan sesuai harapan. Hal ini disebabkan oleh belum adanya SK Penunjukkan Penyelenggaraa Pendidikan Inklusi sehingga pemenuhan berbagai komponen pendukung penyelenggaraan pendidikan inklusi belum bisa terpenuhi secara 


\section{Layanan Bimbingan Dan Konseling ...}

maksimal. Serta belum adanya guru pendamping khusus yang berlatar belakang pendidikan sekolah luar biasa atau bimbingan dan konseling untuk menerapkan pendekatan islami dalam proses layanan.

Mayoritas siswa di SD Bina Harapan Semarang adalah siswa ABK sedangkan guru-guru yang ada adalah guru regular yang minim pengetahuan tentang $\mathrm{ABK}$, adapun pengetahuan dan pelayanan guru yang diberikan kepada siswa ABK di SD Bina Harapan Semarang bersifat otodidak karena penanganan keseharian/kebiasaan menangani siswa ABK sehari-hari saja.

Saran yang dapat diberikan dalam penelitian ini diantaranya adalag: bagi pemerintah terkait perlu memperjelas dan mengelola serta meninjau kembali perizinan serta implementasinya di sekolah dan membuat regulasi yang secara khusus menangani penyelenggaraan pendidikan inklusi terkait dengan kenyataan bahwa di sekolah meyoritas siswa adalah ABK sedangkan kurikulum yang digunakan adalah kurikulum regular. Bagi sekolah yang mempunyai siswa $\mathrm{ABK}$ harus aktif mengupayakan pemenuhan kebutuhan siswa ABK dalam segala hal sesuai dengan kebutuhan masing-masing ABK. Bagi guru sudah semestinya meningkatkan pengetahuan tentang pendidikan inklusi dan pendampingan secara mendalam kepada siswa ABK khususnya penggunaan metode maupun pendekatan islami bagi $\mathrm{ABK}$. 


\section{Eka Sari Setianingsih}

\section{DAFTAR PUSTAKA}

Asyhabuddin. 2008. "Difabilitas dan Pendidikan Inklusi: Kemungkinannya di STAIN Purwokerto". INSANIA: Jurnal Pemikiran Alternatif Pendidikan. Vol. 13, No. 3, Sep-Des 2008, hlm 406-519.

Baker, Edward T., Margaret C. Wang and Herbert J. Walberg. 1994/1995."Synthesis of Research: The Effects of Inclusion on Learning”. Educational Leadership, 52, pp 33-35.

Borg dan Gall. 1983. Educational Research: An Introduction. New York: Allyn and Bacon Inc.

Delphie, Bandi. 2006. Pembelajaran Anak Tunagrahita; Suatu Pengantar dalam Pendidikan Inklusi. Bandung: PT. Refika Aditama.

Direktorat Pendidikan Sekolah Luar Biasa (PSLB). 2007. Pedoman Umum Penyelenggaraan Pendidikan Inklusi. Jakarta: Direktorat Pendidikan Sekolah Luar Biasa (PSLB) Direktorat Jenderal Manajemen Pendidikan Dasar dan Menengah (Mandikdasmen) Kementrian Pendidikan Nasional (Kemendiknas).

Friend, Marilyn \& William D. Bursuck. 2015. Menuju Pendidikan Inklusi: Panduan prkatis untuk mengajar. Yogyakarta: Pustaka Pelajar.

Hallahan, Daniel P., James M. Kauffman, and Paige C. Pullen. 2009. Exceptional Learners: An Introduction to Special Education. Boston: Pearson Education Inc.

Hildegum Olsen. 2003. Pendidikan Inklusi Suatu Strategi Manuju Pendidikan Untuk Semua (Materi Lokakarya)Mataram : Direktorat PSLB.

Ishartiwi. 2010. "Implementasi Pendidikan Inklusi Bagi Anak Berkebutuhan Khusus dalam Sistem Persekolahan Nasional". Jurnal Pendidikan Khusus. Vol. 6 No. 1. Mei 2010, hlm. 1 - 9.

Kustawan, Dedy. 2012. Pendidikan Inklusi dan Upaya Implementasinya. Jakarta: Luxima Metro Media.

Moleong, Lexy J. 2001. Metode Penelitian Kualitatif. Bandung: Remaja Rosdakarya. 


\section{Layanan Bimbingan Dan Konseling ...}

Peraturan Menteri Pendidikan Nasional Nomor 70 Tahun 2009 Tentang Pendidikan Inklusi Bagi Peserta Didik yang Memiliki

Kelainan dan Memiliki Potensi Kecerdasan dan/atau Bakat Istimewa.

Sugiyono. 2010. Metode Penelitian Pendidikan: Pendekatan Kuantitatif, Kualitatif, dan $R \& D$. Bandung: Alfabeta.

Sukinah. 2010. Manajemen Strategik Implementasi Pendidikan Inklusi. Jurnal Pendidikan Khusus. Vol.7 No.2 November 2010: 50 .

Sutrisno. 2012. "Signifikansi Pendidikan Inklusi dalam Mewujudkan Pendidikan untuk Semua". Mukaddimah, Vol. 18, No. 1, 2012, hlm. $31-40$.

Tarmansyah. 2009. "Pelaksanaan Pendidikan Inklusi di SD Negeri 03 Alai Padang Utara Kota Padang (Studi Pelaksanaan Pendidikan di Sekolah Ujicoba Sistem Pendidikan Inklusi )". PEDAGOGI: Jurnal Ilmiah Ilmu Pendidikan, Volume IX No.1 April 2009, hlm. 1 - 16. 